his professor of chemistry, in 1889, and at the end of the same year he emigrated to the United States of America.

In the United States Baekeland devoted the earlier part of his career to research work which resulted in his discovering a process for the production of photographic printing paper, suitable for use in artificial light. To these papers he gave the name 'Velox', which printing paper is still well known throughout the world. In 1893 he founded the Nepera Chemical Co., and in 1898 he sold his interest to the Eastman Kodak Co.

Afterwards, at the age of thirty-five, he returned to research work in a laboratory in a house at Yonkers, near New York, where he worked on various chemical problems, including those connected with resinous products, and made a study of the reaction between phenol and formaldehyde. In 1907 his United States patent on the process for producing phenolformaldehyde resins under control was filed, and this patent became world-famous. In 1909 he read a paper on "The Synthesis, Constitution and Uses of Bakelite" before the New York Section of the American Chemical Society, in which he described in considerable detail the researches which led up to this patent.

In 1910 the Bakelite Gesellschaft was founded in Germany; six months later the General Bakelite Company of America was founded, both companies being for the large-scale production of phenolic resinous materials, known as 'Bakelite' materials. The latter company with the Redmanol Chemical Products Co. and the Condensite Co. of America was afterwards merged into the Bakelite Corporation, of which Dr. Baekeland was the president in 1922.

It was due to Dr. Baekeland's fine personality, initiative and far-sightedness that Bakelite Ltd. in England was formed by an amalgamation of interests which were active in the synthetic resin field.

Many honours were bestowed upon him. He was a commander of the Belgian Order of Leopold, an officer of the Order of the Belgian Crown and an officer of the Order of the French Legion of Honour. For many years he was president of the American
Chemical Society. The W. H. Nichols Medal was presented to him in 1909 ; in 1910 he received the John Scott Medal of the Franklin Institute, and in 1913 he received the Willard Gibbs Medal. When be belonged to the Instruction Board of the Columbia University, he was presented by that University with the Chandler Medal. He was an active member of the Society of Chemical Industry, which in 1916 presented him with the William Perkin Medal of the New York Section of the Society of Chemical Indus. try. In 1915 he was made a doctor of chemistry honoris causa of the University of Pittsburgh. He was also president of the American Institute of Chemical Engineers and of the American Electrochemical Society. In 1938 he was presented with the Messel Medal of the Society of Chemical Industry.

Dr. Baekeland was a member of the U.S. Naval Consulting Board since 1915, a member of the U.S. Nitrate Supply Commission in 1917, and chairman of the Committee on Patents of the National Research Council. He was also a trustee of the Institute of International Education since 1919, and a member of the Advisory Board of the Chemical Division of the U.S. Department of Commerce since 1925.

WE regret to announce the following deaths :

Sir Colin Fraser, director of materials supply of the Australian Department of Munitions and chair. man of the Commonwealth Minerals Committee, and a past president of the Australian Institute of Mining and Metallurgy, on March 10, aged sixty-eight.

Prof. A. E. Jolliffe, emeritus professor of mathematics in the University of London. King's College, on March 17, aged seventy-three.

Dr. A. W. Pollard, formerly keeper of printed books in the British Museum and honorary secretary of the Ribliographical Society, on March 8, aged eightyfour.

Sir David Prain, C.M.G., C.I.E., F.R.S., lately director of the Royal Botanic Gardens, Kew, on March 16, aged eighty-six.

\title{
NEW FELLOWS OF THE ROYAL SOCIETY
}

The following were elected fellows of the Royal Society on March 16 :

BRIGADIER R.A. BAGNOLD, explorer ; distinguished for scientific work on desert topography, and in particular for his precise studies of the physical principles governing the movements and deposition of sand under the action of wind.

Mr. R. P. BeLr, fellow of Balliol College, Oxford ; distinguished for his theoretical and practical contributions to physical chemistry, particularly the studies of reaction rates in solutions, and the applications of wave-mechanics.

DR. C. R. BuRCH, research physicist, University of Bristol ; distinguished for original research in many branches of applied physics, particularly on the methods for attaining high vacua.

Pror. Subramanya Chandrasekhar, associate professor in the University of Chicago, formerly fellow of Trinity College, Cambridge; distinguished for his contributions to theoretical astronomy and astrophysics, particularly relating to stellar structure and the dynamics of stellar systems.
Mr. G. E. R. Deacon, member of the scientific staff of the "Discovery" Committee of the Colonial Office ; distinguished for outstanding work, particularly in the Southern oceans, on physical oceanography and marine zoology, and the relations between them.

Sir JACK Drummond, professor of biochemistry, University College, London, and chief scientific adviser to the Ministry of Food, distinguished for his work on practical nutrition.

DR. A. T. GLENNY, immunologist, Wellcome Physiological Research Laboratories, Beckenham, distinguished for his work on immunity and its application to the immunization of man and animals, especially against diphtheria and tetanus.

DR. R. G. Hatton, director of the Fruit Research Station, East Malling; the pioneer of scientific pomology in Great Britain ; the research work which he has organized and directed in this field has a world-wide reputation.

Prof. R. D. Haworth, professor of chemistry, University of Sheffield; his contributions to the 
structure of natural products are of outstanding importance, and by his synthetical investigations he has added greatly to our knowledge of the lignans.

DR. W. O. Kermack, research chemist at the Royal College of Physicians, Edinburgh; disinguished especially for his contributions to the knowledge of alkaloids and of synthetic therapeutic compounds; and also for his original contributions to mathematics and statistics in subjects of medical interest.

Dr. Frankuin KIDD, superintendent of the Low Temperature Research Station, Cambridge; he has made important contributions to the study of respiration of fruits and is well known for his work on the gas storage and low-temperature conservation of apples.

Prof. B. A. McSwiney, professor of physiology, St. Thomas's Hospital, University of London; distinguished for his researches on the afferent nerves from the viscera and on the control of visceral move. ments.

Prof. G. F. Marrian, professor of medical chemistry, University of Edinburgh ; distinguished for his work in biochemistry, especially on the female sex hormones and related substances.

Prof. M. Polanyr, professor of physical chemistry, University of Manchester ; distinguished for his fundamental work on elementary reactions, for his theory of chemical activation energies and for many other important contributions to physics and chemistry.
Mr. A. SAND, comparative physiologist, Marine Biological Station, Plymouth ; distinguished for his studies of the respiratory mechanisms of invertebrates, the pigmentary effector system of reptiles and the sense organs and locomotor mechanisms in fishes.

Srr WiLliam Stanier, chief mechanical engineer, L.M.S. Railway, scientific adviser to the Minister of Production; distinguished as a locomotive engineer and particularly for his services in the application of science to mechanical engineering.

Dr. C. J. Stubblefreld, senior geologist, Geological Survey of Great Britain; distinguished for his knowledge of the invertebrates of the earlier geological formations ; especially for his researches on the life-history, classification and migration of trilobites, and the inter-relationships of graptolites.

Dr. O. W. TIEGS, zoologist, University of MeI. bourne ; distinguished for his histological and physiological work; in particular for his studies on the embryology and metamorphosis of insects.

DR. H. J. VAN DER BIJL, director of war supply, Union of South Africa; research physicist; distinguished for his electrical researches, particularly on the conduction of electricity through gases, and for his services with regard to the application of science to industry in South Africa.

Mr. J. H. C. WHITEHEAD, University lecturer and fellow of Balliol Crllege, Oxford ; distinguished for his varied contributions to pure mathematics, particularly in combinatorial topology, the theory of groups and of group-rings.

\section{NEWS and VIEWS}

\section{University of Edinburgh : Chair of Public Health}

THE University Court of the University of Edinburgh, in appointing Prof. F. A. E. Crew to the Bruce and John Usher chair of public health, has made an interesting and significant break with tradition. Prof. Crew's association with the Univer. sity, as teacher and research worker, began in the Department of Zoology and continued in the Institute of Animal Genetics, of which he became the first director in 1921, and the first occupant of the Buchanan chair of animal genetics in 1928. In the Institute he gathered about him a notable band of scientific workers from many nations, and these he inspired with his own enthusiasm, so that a steady stream of the results of research in various directions issued from the laboratories. Prof. Crew's transference from animal genetics to public health indicates a change of outlook in health teaching in relation to the populace. In place of emphasizing, as established courses of instruction have done, aspects of control of infection and the improvement of health by better methods of sanitation and environmental conditions in general, the new outlook, from a biological background, envisages a drive for positive health education backed by tuition in social biology and social medicine.

It is obvious that such development of a biological background in public health education cannot entirely take the place of the detailed knowledge of methods of promoting public sanitation and hygiene, which formed a main part of the established and welltried course, and of which Prof. P. S. Lelean, who is about to retire from the chair of public health in the University, was so capable and thorough-going an exponent. Advantage has therefore been taken of the excellence of the public health services to enlist their aid, and by arrangement between the University and the Corporation of Edinburgh, the Medical Officer of Health, Dr. W. G. Clark, and the staff of the Public Health Department, will collaborate in that part of the course which deals with the application of science to the control of infectious diseases, to public sanitation and to environmental hygiene. Thus it is hoped to develop a comprehensive curriculum in health and social medicine, to which other specialized departments of university study may make their own individual contributions.

\section{Research Workers in Industry}

IN the second of the series of addresses on science and industry to the Manchester Chamber of Commerce, delivered on March 16, Dr. A. P. M. Fleming spoke on "Research Workers: Their Education and Place in Industry". Dr. Fleming pointed out that there are only two broad types of research workers: those engaged in pursuit of knowledge for its own sake; and those engaged in applying new discoveries to useful purposes. The latter bridge the gap between the investigations of the fundamental research worker and industry, and Dr. Fleming stressed the importance of such workers having some industrial experience appropriate to their scientific studies although the training required may differ in different industries. In chemical industry, for example, a postgraduate course in an advanced field of chemistry might be followed for a few years before entering an industrial laboratory. An engineer might be advised to leave the university on graduation and spend a 